\title{
Gas Phase Reaction of Substituted Isoquinolines to Carboxylic Acids in Ion Trap and Triple Quadrupole Mass Spectrometers after Electrospray Ionization and Collision- Induced Dissociation
}

\author{
Mario Thevis, ${ }^{\mathrm{a}}$ Maxie Kohler, ${ }^{\mathrm{a}}$ Nils Schlörer, ${ }^{\mathrm{b}}$ and Wilhelm Schänzer ${ }^{\mathrm{a}}$ \\ ${ }^{a}$ Center for Preventive Doping Research, Institute of Biochemistry, German Sport University Cologne, \\ Cologne, Germany \\ ${ }^{\mathrm{b}}$ Institute of Organic Chemistry, University of Cologne, Cologne, Germany
}

\begin{abstract}
Within the mass spectrometric study of bisubstituted isoquinolines that possess great potential as prolylhydroxylase inhibitor drug candidates (e.g., FG-2216), unusually favored gas-phase formations of carboxylic acids after collisional activation were observed. The protonated molecule of [(1-chloro-4-hydroxy-isoquinoline-3-carbonyl)-amino]-acetic acid was dissociated, yielding the 1-chloro-4-hydroxy-isoquinoline-3-carboxylic acid methyleneamide cation. Subsequent dissociation caused the nominal elimination of $11 \mathrm{u}$ that resulted from the loss of HCN and concomitant addition of oxygen to the product ion, which formed the protonated 1-chloro-4-hydroxy-isoquinoline-3-carboxylic acid. The preference of this structure under mass spectrometric conditions was substantiated by tandem mass spectrometry analyses using the corresponding methyl ester (1-chloro-4-hydroxy-isoquinoline-3-carboxylic acid methyl ester) that eliminated methylene $(-14 \mathrm{u})$ upon collisional activation. Moreover, the major product ion of 1-chloro-4-hydroxy-isoquinoline-3-carboxylic acid, which resulted from the loss of water in $\mathrm{MS}^{3}$ experiments, restored the precursor ion structure by re-addition of $\mathrm{H}_{2} \mathrm{O}$. Evidences for these phenomena were obtained by chemical synthesis of proposed gas-phase intermediates, $\mathrm{H} / \mathrm{D}$ exchange experiments, high-resolution/high accuracy mass spectrometry at $\mathrm{MS}^{\mathrm{n}}$ level, and "ping-pong" analyses (MS7, in which the precursor ion was dissociated and the respective product ion isolated to regenerate the precursor ion for repeated dissociation. Based on these results, dissociation pathways for [(1-chloro-4-hydroxy-isoquinoline-3-carbonyl)-amino]-acetic acid were suggested that can be further utilized for the characterization of structurally related compounds or metabolic products in clinical, forensic, or doping control analysis. (J Am Soc Mass Spectrom 2008, 19, 151-158) @ 2008 American Society for Mass Spectrometry
\end{abstract}

$\mathrm{P}$ rolyl hydroxylases have been subject of various studies because of their importance in several biochemical pathways and, thus, related diseases in case of impaired activity. Proline hydroxylation was identified as a key factor in the biosynthesis and maturation of collagen [1,2], which requires 4-hydroxylation of specific proline residues (in X-Pro-Gly motifs) to establish the characteristic triple-helical structure. However, during life-threatening fibrotic states, inappropriately large amounts of collagen are produced, and the inhibition of proline hydroxylation is desired to divert the collagen biosynthesis into a degradative pathway [3]. More recently, the catalytic role of prolyl hydroxylase isoforms in modifying conserved prolines of two oxygen-dependent degradation domains in the hypox-

Address reprint requests to Dr. Mario Thevis, Institute of Biochemistry, Center for Preventive Doping Research, German Sport University Cologne, Carl-Diem Weg 6, 50933 Cologne, Germany. E-mail: m.thevis@biochem. dshs-koeln.de ia-inducible factor (HIF)- $1 \alpha$ was identified [4-6]. The members of the 2-oxoglutarate-dependent dioxygenase superfamily enable the hydroxylation of the proline residues 402 and 564 of HIF- $1 \alpha$ and promote its degradation via ubiquitylation and subsequent proteasomal destruction [7-9]. As a consequence, the presence of HIF- $1 \alpha$ in organisms is regulated in an oxygen-dependent manner, which represents the basis of cellular oxygen sensing [10-12] and, thus, the activity of hypoxic response genes that control angiogenic $[13,14]$ and erythropoietic processes [15-17].

Based on these findings and the involved molecular principles, numerous compounds were designed and tested regarding their properties to inhibit prolyl hydroxylase activities to counteract and correct symptoms of serious diseases. Derivatives of 2-oxoglutarate [18, 19], hydroxyanthraquinones [20], 5-acyl sulfonamides [21], dihydroxybenzoates [22], hydroxyquinolines [23], pyrazolopyridines [24], and many other compounds [25-28] were 
<smiles>[R]Cc1nc(C(=O)NCC(=O)O)c(O)c2c([R3])c([R3])c([R2])c([R3])c12</smiles><smiles>O=C(O)CNC(=O)c1nc(Cl)c2ccccc2c1O</smiles><smiles>O=C(O)c1nc(Cl)c2ccccc2c1O</smiles><smiles>COC(=O)c1nc(Cl)c2ccccc2c1O</smiles><smiles>O=C(O)CNC(=O)c1nc(Cl)c2ccccc2c1O</smiles>

Scheme 1. Chemical structures of investigated: 1, general structure of isoquinoline-3-carboxylamide-based prolylhydroxylase inhibitors, 2, drug candidate ( $\mathrm{mol} \mathrm{wt}$ monoisotopic $=280)$, 3, 1-chloro4-hydroxy-isoquinoline-3-carboxylic acid (mol wt $\mathrm{t}_{\text {monoisotopic }}=$ 223), 4, 1-chloro-4-hydroxy-isoquinoline-3-carboxylic acid methyl ester $\left(\mathrm{mol} \mathrm{wt}_{\text {monoisotopic }}=237\right)$, and 5 , drug candidate 2 after $\mathrm{H} / \mathrm{D}$-exchange in $\mathrm{D}_{2} \mathrm{O} / \mathrm{MeOD}$ (mol $\mathrm{wt}_{\text {monoisotopic }}=283$ ). R1-R5 represent various substituents, e.g., hydrogens, halogens, hydroxyl functions, alkyl, or alkyloxy residues, etc.

prepared and studied. One of the most promising class of candidates, which currently undergoes Phase II clinical trials [29], comprises an isoquinoline core with a 3-positioned carboxyl residue that was converted into its amide using glycine (Scheme 1-1). Various studies proved the efficiency of the lead drug candidate FG-2216, an orally active compound, in stimulating erythropoiesis for the treatment of anemia [30,31]. In the course of analytical assay development concerning model prolyl hydroxylase inhibitors (PHIs), the isoquinoline-derived PHI [(1-chloro4-hydroxy-isoquinoline-3-carbonyl)-amino]-acetic acid was synthesized, and subsequently studied using electrospray ionization and high-resolution/high accuracy ion trap/ orbitrap mass spectrometry. Diagnostic product ions characterizing the target analyte and related compounds were elucidated in $\mathrm{MS}^{\mathrm{n}}$ experiments with in-time and in-space dissociation as well as comparison of ions formed under gas-phase conditions with chemically synthesized reference substances. The obtained results provided evidence for gas-phase reactions that include the addition of oxygen as well as water generating a favored ion with isoquinoline-3-carboxylic acid structure. The resulting data on the dissociation behavior of structural analogs shall support the identification of such compounds and/or metabolites in clinical, forensic, and doping control analysis.

\section{Experimental}

To allow method developments aiming at clinical, forensic, or preventive doping research, therapeutics in clinical studies or structural analogs that resemble physicochemical properties of future drug candidates are studied using informative and sensitive analytical tools such as mass spectrometry, which are applicable also to biological matrices.

\section{Chemicals and Reagents}

Phthalic anhydride (99\%), methyl isocyanoacetate (97\%), phosphorus oxychloride $(99 \%)$, glycine methyl ester hydrochloride (99\%), (benzotriazol-1-yloxy)tripyrrolidinophosphonium hexafluorophosphate (PyBOP, $98 \%$ ), triethylamine (99\%), N-ethyldiisopropylamine $(98 \%)$, deuterium oxide $\left(\mathrm{D}_{2} \mathrm{O}, 99.9 \%\right)$, and water $-{ }^{18} \mathrm{O}$ $(10 \%)$ were purchased from Sigma (Deisendorf, Germany). Silica gel 60 (70-230 mesh) and solvents (methanol, tetrahydrofurane, dichloromethane, and dimethylformamide, all analytical grade) were obtained from Merck (Darmstadt, Germany). Deionized water used for sample preparation and buffer solutions was of MilliQ grade.

\section{Synthesis and Characterization of Model Compound}

One model PHI, [(1-chloro-4-hydroxy-isoquinoline-3-carbonyl)-amino]-acetic acid (Scheme 1-2) and related derivatives were synthesized as described elsewhere [32, 33]. Briefly, phthalic anhydride and methyl isocyanatoacetate were mixed to yield to 5-(2-carboxyphenyl)-4-methoxycarbonyl-1,3-oxazole, which was further condensed to methyl 4-hydroxy-1-oxo-1,2-dihydroisoquinoline-3-carboxylate, which is referred to as Compound 4 (Scheme 1) that allowed the preparation of Compound 3 (Scheme 1) after alkaline hydrolysis. Subsequent chlorination at C-1, amide formation at the 3-carboxyl function using glycine methyl ester, and alkaline hydrolysis gave rise to Compound 2. After purification using flash chromatography (dichloromethane and silica gel), the pure reference compound was characterized by nuclear magnetic resonance spectroscopy (NMR) with ${ }^{1} \mathrm{H}, \mathrm{H}, \mathrm{H}-\mathrm{COSY}, \mathrm{H}, \mathrm{C}$ HMQC, $\mathrm{H}, \mathrm{C}$ HMBC, and DEPT experiments employing a Bruker DRX $500 \mathrm{MHz}$ instrument (Bruker, Karlsruhe, Germany) equipped with a $5 \mathrm{~mm}$ inverse probe head (z-gradient coil). Approximately $10 \mathrm{mg}$ of 2 was dissolved in deuterated dimethylsulfoxide, and spectra were recorded at room temperature. In addition, the elemental composition of the synthesized substance was determined using highresolution/high accuracy mass spectrometry utilizing an LTQ Orbitrap (Thermo, Bremen, Germany) at a resolving power of 30,000 (FWHM).

\section{Stock and Working Solutions}

The stock solutions of the analytes was prepared in acetonitrile at $1 \mathrm{mg} / \mathrm{mL}$ and stored at 2 to $8{ }^{\circ} \mathrm{C}$. Working solutions were prepared at $2 \mu \mathrm{g} / \mathrm{mL}$ using acetoni- 
trile and water (1:1, vol:vol) acidified with $0.5 \%$ of formic acid.

\section{Electrospray Ionization-Tandem Mass Spectrometry}

ESI-MS(/MS) was performed on a LTQ Orbitrap (Thermo, Bremen, Germany) mass spectrometer. The instrument was operated in positive ionization mode and calibrated using the manufacturer's calibration mixture (containing caffeine, MRFA, and Ultramark that yield a total of seven reference masses). Mass accuracies $<2$ ppm (calculated from 30 averaged spectra) were determined before and after the period of analysis of target compounds. Working solutions were introduced into the mass spectrometer using a syringe pump at a flow rate of $5 \mu \mathrm{L} / \mathrm{min}$. The ionization voltage was $3.0 \mathrm{kV}$, the capillary temperature was set to $275^{\circ} \mathrm{C}$, and protonated precursor ions were isolated using a width of 1.4 Da. The protonated species were dissociated at normalized collision energies between 10 and 35 (arbitrary units). Damping gas in the linear ion trap was helium (purity grade 5.0), and gas supplied to the curved linear ion trap (CLT) was nitrogen obtained from a CMC nitrogen generator (CMC Instruments, Eschborn, Germany).

\section{$H / D$-Exchange Experiments}

To provide more detailed mass spectrometric information for product ion characterization and suggestion of dissociation pathways, hydrogen/deuterium-exchange was performed by dissolving $1 \mathrm{mg}$ of Compound 2 in 1 $\mathrm{mL}$ of deuterated methanol (MeOD) and deuterium oxide $\left(\mathrm{D}_{2} \mathrm{O}\right)(1: 1, \mathrm{vol}: \mathrm{vol})$. After incubation at room temperature for $10 \mathrm{~min}$, the solution was diluted 1:50 in MeOD/ $\mathrm{D}_{2} \mathrm{O}$ (1:1, vol:vol) and introduced into the LTQ Orbitrap mass spectrometer via the syringe pump. Analyses were carried out under identical conditions as applied for Compound 2 without H/D-exchange.

\section{Liquid Chromatography-Tandem Mass Spectrometry}

Additional mass spectrometric studies were performed using an Agilent 1100 Series liquid chromatograph (Waldbronn, Germany) coupled to an Applied Biosystems API 4000 QTrap mass spectrometer (Darmstadt, Germany) with electrospray ionization to probe for differences in dissociation pathways using in-space instead of in-time tandem mass spectrometry and nitrogen as collision gas. The LC was equipped with a Macherey-Nagel Pyramid column $(4.0 \times 70 \mathrm{~mm}, 5 \mu \mathrm{m}$ particle size), and the eluents used were $5 \mathrm{mM}$ ammonium acetate containing $0.1 \%$ acetic acid (mobile phase A) and acetonitrile/methanol (1:1, vol:vol; mobile phase B). A gradient was employed starting at $0 \%$ B (1 min) increasing to $100 \% \mathrm{~B}$ within $6.5 \mathrm{~min}$ followed by re- equilibration at $0 \% \mathrm{~B}$ for $1.5 \mathrm{~min}$. The flow rate was set to $800 \mu \mathrm{L} / \mathrm{min}$. Nitrogen was employed as curtain and collision gas $\left(5 \times 10^{-3} \mathrm{~Pa}\right)$ delivered from a $\mathrm{CMC}$ nitrogen generator (CMC Instruments, Eschborn, Germany), and collision offset voltages or nozzle-skimmer dissociation settings were optimized for each experiment (vide infra).

\section{Results and Discussion}

\section{Synthesis and Characterization of the Model PHI [(1-Chloro-4-Hydroxy-Isoquinoline-3-Carbonyl)- Amino]-Acetic Acid}

The synthesis yielded the intended structure with an overall yield $8.6 \%$, which provided sufficient amounts of pure analyte necessary for structure characterization and mass spectrometric studies. Compound 2 was characterized by NMR analyses: ${ }^{1} \mathrm{H}$ NMR (500 MHz, $\mathrm{d}_{6}$-DMSO) $\delta: 8.35$ (m, 1H, H-5), 7.99 (m, 1H, H-6), 7.99 (m, 1H, H-7), 8.35 (m, 1H, H-8), 4.05 (d, 2H, H-13); ${ }^{13} \mathrm{C}$

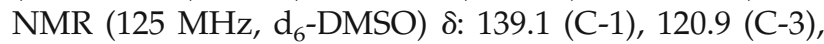
155.0 (C-4), 123.5 (C-5), 132.2 (C-6), 132.2 (C-7), 126.6 (C-8), 130.0 (C-9), 129.0 (C-10), 169.3 (C-11), 41.35 (C-13), $171.1(\mathrm{C}-14)$.

\section{Electrospray Ionization-tandem Mass Spectrometry}

The CID behavior of the model target analyte 2 was studied employing high-resolution/high accuracy (tandem) mass spectrometry with a hybrid linear ion traporbitrap instrument. The characterization of dissociation pathways of new emerging therapeutics is of particular importance in clinical research as well as sports drug testing. Metabolite identification and characterization nowadays strongly relies on mass spectrometric results, which necessitate a comprehensive set of information to assign dissociation pathways to analyte structures in complex biological matrices such as blood or urine.

PHIs have been the subject of various recent studies $[23,24]$, and the product ion spectrum of 2 derived from the protonated molecule $[\mathrm{M}+\mathrm{H}]^{+}$at $m / z 281$ is depicted in Figure 1a. Upon weak collisional activation (normalized collision energy $=15$ arbitrary units, Xcalibur Software version 2.0; Thermo, San Jose, CA), the precursor ion consecutively eliminates water $(-18 \mathrm{u})$ and carbon monoxide $(-28 \mathrm{u})$ yielding the product ions at $m / z 263$ and 235, respectively. Moreover, a nominal loss of $\mathrm{C}_{2} \mathrm{H}_{3} \mathrm{NO}(-57 \mathrm{u})$ is observed generating the ion at $m / z 224$, which subsequently releases water $(-18 \mathrm{u})$ to yield the product ion at $m / z 206$ (Table 1). By means of $\mathrm{MS}^{3}$ and $\mathrm{MS}^{4}$ experiments, it was demonstrated that the ion at $m / z 235$ gives rise to $m / z 224$ (Figure $1 \mathrm{~b}$ ). This corresponded to a nominal loss of $11 \mathrm{u}$ that was attributed to the elimination of $\operatorname{HCN}(-27 \mathrm{u})$ concerted with an addition of oxygen $(+16 \mathrm{u})$ according to highresolution/high accuracy mass spectrometry results (Table 1). Due to this unusual behavior, various exper- 
iments, including linear ion trap $\mathrm{MS}^{\mathrm{n}}$ and in-space MS/MS, H/D-exchange, as well as synthesis and analysis of putative compounds generated in situ as gasphase ions under CID conditions, were conducted to elucidate the mechanism underlying the observed dissociation behavior.

The influence of ion trapping on the phenomenon of the release of $\mathrm{HCN}$ and the simultaneous addition of oxygen to the ion at $\mathrm{m} / \mathrm{z} 235$ was evaluated using a triple-stage quadrupole tandem mass spectrometer (Applied Biosystems QTrap 4000, see above). Employing an elevated declustering potential of $100 \mathrm{~V}$ that induces a nozzle-skimmer dissociation of the protonated precursor ion to generate $\mathrm{m} / \mathrm{z} 235$, pseudo-MS ${ }^{3}$ measurements were performed that yielded a highly comparable dissociation pattern as observed in ion trap/orbitrap analyses. The major product ions formed from $\mathrm{m} / \mathrm{z} 235$ using in-space CID were found at $\mathrm{m} / \mathrm{z} 224$ and $m / z 206$ (Figure 1c), which allowed the assumption that the rearrangement causing the loss of $\mathrm{HCN}$ and the addition of oxygen did not necessitate ion trapping conditions and was not dependent on resonant excitation of ions. Exchanging hydrogen by deuterium atoms in Compound 2 yielded the precursor ion at $\mathrm{m} / \mathrm{z} 285$ (Scheme 1,5) due to the incorporation of three deuterons plus one replacing the proton, which is added during the ionization process. The dissociation of the deuterated precursor ion $\left[\mathrm{M}_{\mathrm{D} 3}+\mathrm{D}^{+}\right.$provided evidence for the loss of $\mathrm{D}_{2} \mathrm{O}(-20 \mathrm{u})$ followed by the elimination of $\mathrm{CO}(-28)$ giving rise to product ion at $\mathrm{m} / \mathrm{z} 237$ that comprised two deuterium atoms (Table 1). Moreover, product ions at $\mathrm{m} / \mathrm{z} 225$ and 227 were detected, which proved the existence of two dissociation pathways and supposedly two different structures of product ions with identical elemental compositions in case of the unlabeled Compound 2; i.e., the precursor ion of the deuterated Compound 5 eliminated isocyanatomethane containing one deuterium atom $\left(\mathrm{CH}_{2} \mathrm{DNCO},-58 \mathrm{u}\right)$ to yield $\mathrm{m} / \mathrm{z} 227$, while $\mathrm{MS}^{3}$ experiments using $\mathrm{m} / \mathrm{z} 237$ as the second precursor ion generated the product ion at $\mathrm{m} / \mathrm{z} 225$ that resulted from the loss of DCN accompanied by the uptake of one oxygen atom (Table 1). The source of the added oxygen, however, remained unclear. Based on these data, dissociation pathways for the protonated molecule of $\mathbf{2}$ were proposed as illustrated in Scheme 2. Two parallel routes led to the product ion at $m / z 224$, which is assumed to be composed by two species. Route 1 is suggested to be initiated by the losses of water and carbon monoxide (a) that yielded the 1-chloro-4-hydroxy-isoquinoline-3-carboxylic acid methyleneamide cation at $m / z 235$ (Scheme 2). The elimination of HCN (b) can form a highly reactive carbene that subsequently adds oxygen (c) to yield $m / z 224$. In contrast, route 2 is proposed to consist of an immediate release of isocyanatomethane (d) from the protonated molecule. Here, a rearrangement including hydrogen transfer from $\mathrm{N}-2$ to the leaving group and migration of the terminal carboxyl function are suggested because only one deuterium atom was eliminated with the loss of $\mathrm{CH}_{2} \mathrm{DNCO}$ in $\mathrm{H} / \mathrm{D}$-exchange experiments (vide supra).

Supporting information for the suggested structures of the product ions at $\mathrm{m} / \mathrm{z} 235$ and 224 were obtained by further dissociation as well as analyses of synthesized 1-chloro-4hydroxy-isoquinoline-3-carboxylic acid (Scheme 1-3) and its methyl ester (Scheme 1-4). Besides abundant signals at $\mathrm{m} / \mathrm{z} 224$ and 206, the ion at $\mathrm{m} / \mathrm{z} 235$ (derived from Compound 2) yielded a product ion at $m / z 178$ in $\mathrm{MS}^{3}$ experiments (Figure 1b, Table 1). Its generation was assigned to the loss of $\mathrm{N}$-methylene-formamide $\left(\mathrm{CH}_{2} \mathrm{NCHO},-57 \mathrm{u}\right)$, which is possible after isomerization of $\mathrm{m} / \mathrm{z} 235$ with charge delocalization via a facile 1,2-elimination assuming the structure presented in Scheme 2 (e). The CID of the product ion at $\mathrm{m} / \mathrm{z} 224$ mainly yielded an ion resulting from the loss of water only $(\mathrm{m} / \mathrm{z} 206)$ but also products resulting from the consecutive release of CO $(\mathrm{m} / \mathrm{z} 196)$ and water $(\mathrm{m} / \mathrm{z} 178)$ (Figure 1d). The analysis of synthesized 1-chloro-4hydroxy-isoquinoline-3-carboxylic acid (Compound 3), which represents the proposed structure of the product ion at $\mathrm{m} / \mathrm{z} 224$, demonstrated an identical dissociation behavior as the product ion derived from Compound 2, which substantiated the postulated gas-phase ion structure (Figure 1e). Measuring the corresponding methyl ester of 1-chloro-4-hydroxy-isoquinoline-3-carboxylic acid (Compound 4 ) under identical conditions gave rise to a product ion spectrum depicted in Figure 1f. The protonated molecule at $m / z 238$ generated an abundant signal upon collisional activation at $\mathrm{m} / \mathrm{z} 224$, which represented the free carboxylic acid and, thus, demonstrated the favored gas-phase ion structure of $m / z 224$ as the loss of methylene is rather seldom using ESI and CID.

Finally, the preferred generation of $\mathrm{m} / \mathrm{z} 224$ was further substantiated by isolation of its major product ion at $\mathrm{m} / \mathrm{z} 206$ (Scheme 2). The isolation and storage of $\mathrm{m} / \mathrm{z} 206$ in the linear ion trap without excitation enabled the restoration of $\mathrm{m} / \mathrm{z} 224$ by the re-addition of water

Figure 1. ESI product ion spectra of (a) Compound 2, LTQ-Orbitrap, collision energy $=15$ arbitrary units; (b) Compound 2, LTQ-Orbitrap, MS $^{3}$ experiment on $m / z$ 281-235, collision energy $=17$ arbitrary units; (c) Compound 2, API 4000 QTrap, pseudo-MS ${ }^{3}$ experiment on $\mathrm{m} / \mathrm{z} 235$, declustering potential = $100 \mathrm{~V}$, collision offset voltage $=20 \mathrm{~V}$; (d) Compound 2, LTQ-Orbitrap, MS ${ }^{3}$ experiment on $\mathrm{m} / \mathrm{z}$ 281-224, collision energy $=25$ arbitrary units; (e) Compound 3, LTQ-Orbitrap, (1-chloro-4-hydroxyisoquinoline-3-carboxylic acid), collision energy = 40 arbitrary units; and (f) Compound 4, LTQOrbitrap, (1-chloro-4-hydroxy-isoquinoline-3-carboxylic acid methyl ester), collision energy $=17$ arbitrary units. 
a)

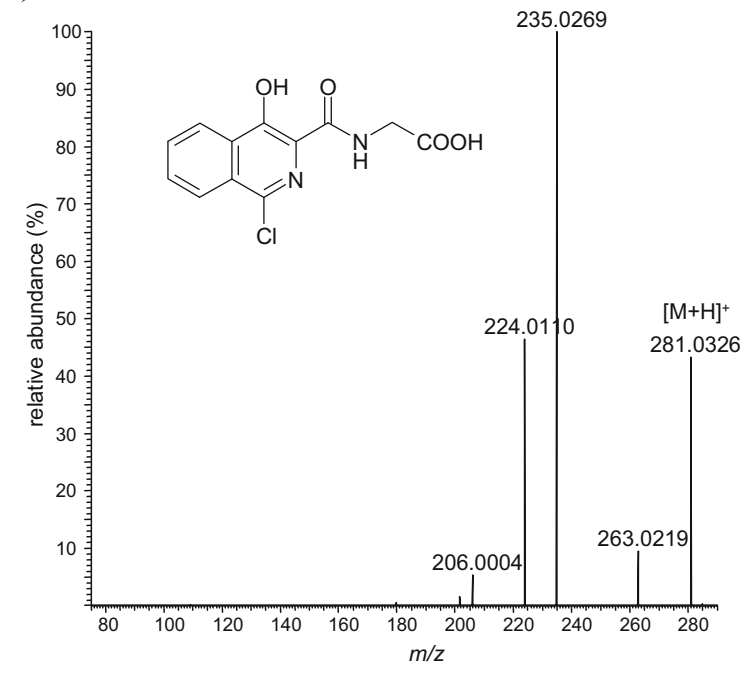

c)

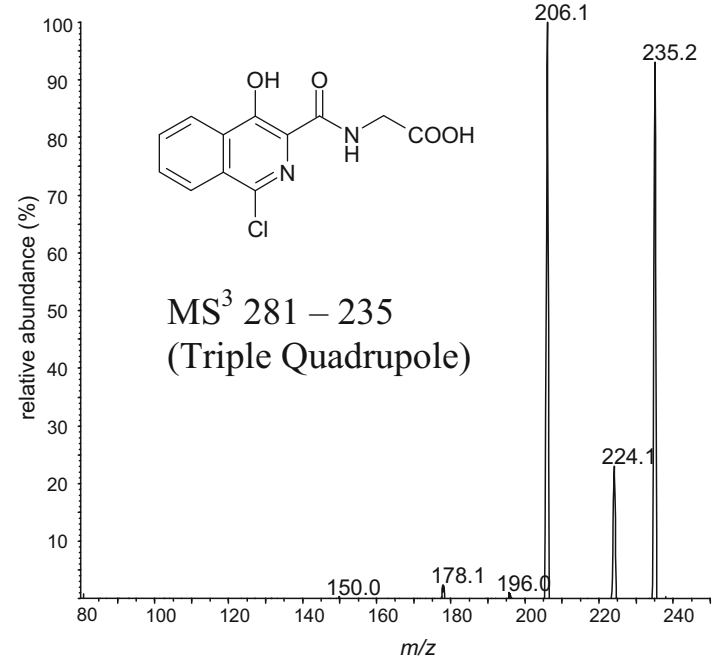

e)

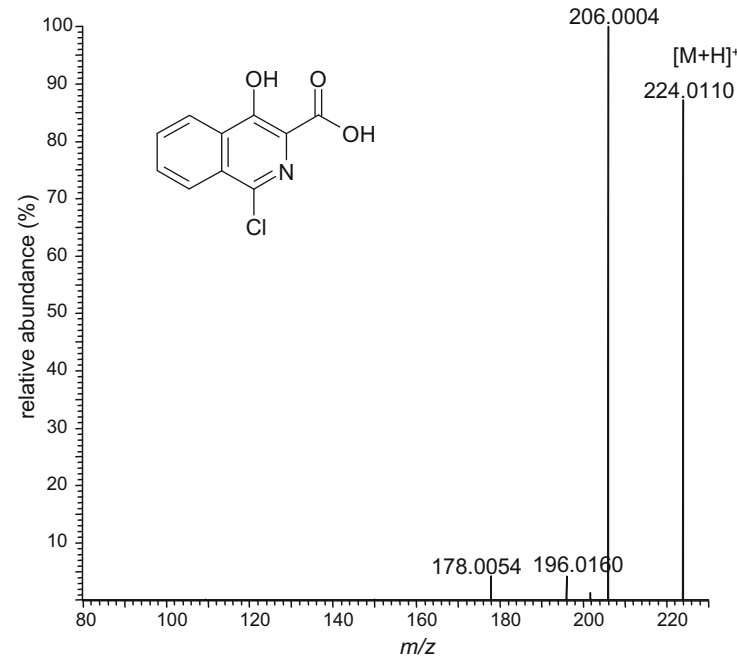

b)

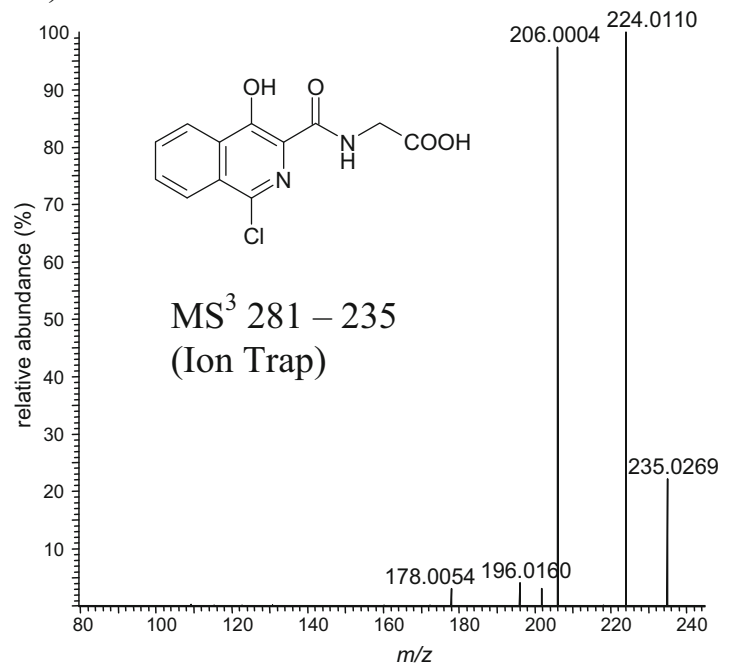

d)

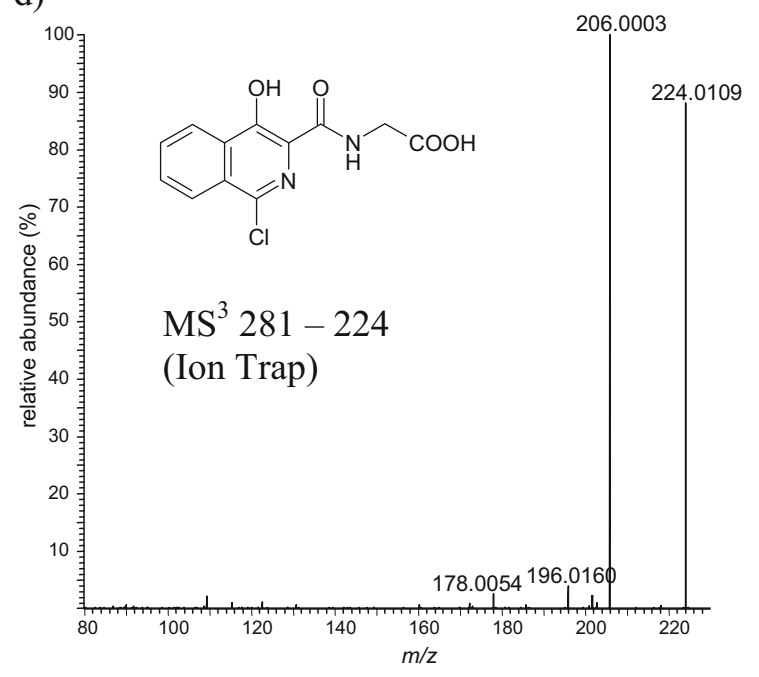

f)

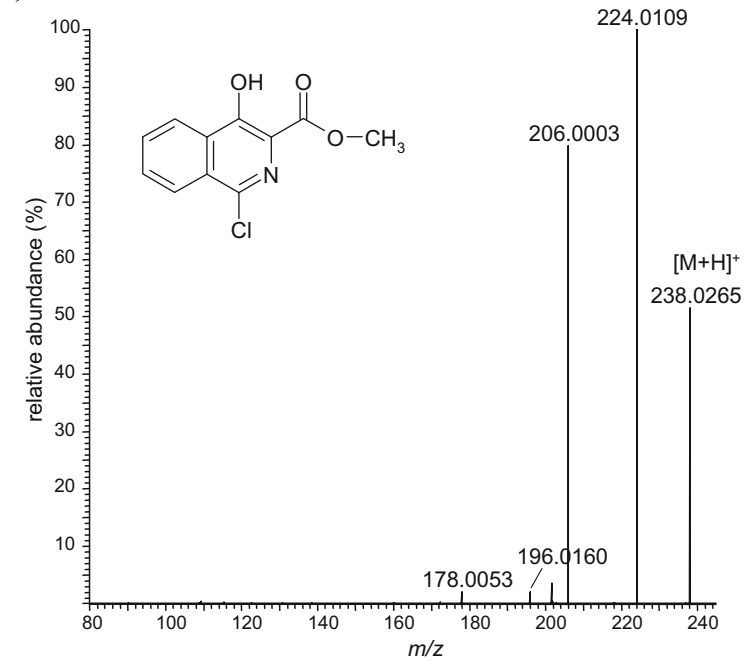


Table 1. Elemental compositions of protonated molecules and resulting product ions using high resolution/high accuracy $\mathrm{MS}^{\mathrm{n}}$ experiments

\begin{tabular}{|c|c|c|c|c|c|c|c|c|c|c|}
\hline \multirow{2}{*}{$\begin{array}{l}\text { Com- } \\
\text { pound }\end{array}$} & \multicolumn{3}{|c|}{ Precursor ion $(\mathrm{m} / \mathrm{z})$} & \multirow{2}{*}{$\begin{array}{l}\text { Elemental } \\
\text { comp. (exp.) }\end{array}$} & \multirow[b]{2}{*}{$\begin{array}{c}\text { Error } \\
(\mathrm{ppm})\end{array}$} & \multirow{2}{*}{$\begin{array}{l}\text { Collision } \\
\text { energy } \\
\text { (arb. units) }\end{array}$} & \multirow{2}{*}{$\begin{array}{l}\text { Product } \\
\text { ion }(\mathrm{m} / \mathrm{z})\end{array}$} & \multirow{2}{*}{$\begin{array}{l}\text { Elemental } \\
\text { comp. (exp.) }\end{array}$} & \multirow{2}{*}{$\begin{array}{r}\text { Error } \\
(\mathrm{ppm})\end{array}$} & \multirow{2}{*}{$\begin{array}{l}\text { Cleaved } \\
\text { species }\end{array}$} \\
\hline & $\mathrm{MS}^{2}$ & $\mathrm{MS}^{3}$ & $\mathrm{MS}^{4}$ & & & & & & & \\
\hline \multirow[t]{16}{*}{2} & 281.0326 & & & $\mathrm{C}_{12} \mathrm{H}_{10} \mathrm{O}_{4} \mathrm{~N}_{2} \mathrm{Cl}$ & 0.7 & 15 & 263.0219 & $\mathrm{C}_{12} \mathrm{H}_{8} \mathrm{O}_{3} \mathrm{~N}_{2} \mathrm{Cl}$ & 0.3 & $\mathrm{H}_{2} \mathrm{O}$ \\
\hline & & & & & & & 235.0269 & $\mathrm{C}_{11} \mathrm{H}_{8} \mathrm{O}_{2} \mathrm{~N}_{2} \mathrm{Cl}$ & 0.1 & $\mathrm{H}_{2} \mathrm{O}, \mathrm{CO}$ \\
\hline & & & & & & & 224.0110 & $\mathrm{C}_{10} \mathrm{H}_{7} \mathrm{O}_{3} \mathrm{NCl}$ & 0.4 & $\mathrm{C}_{2} \mathrm{H}_{3} \mathrm{NO}$ \\
\hline & & & & & & & 206.0004 & $\mathrm{C}_{10} \mathrm{H}_{5} \mathrm{O}_{2} \mathrm{NCl}$ & 0.3 & $\mathrm{C}_{2} \mathrm{H}_{3} \mathrm{NO}, \mathrm{H}_{2} \mathrm{O}$ \\
\hline & & 263.0219 & & $\mathrm{C}_{12} \mathrm{H}_{8} \mathrm{O}_{3} \mathrm{~N}_{2} \mathrm{Cl}$ & 0.3 & 10 & 235.0269 & $\mathrm{C}_{11} \mathrm{H}_{8} \mathrm{O}_{2} \mathrm{~N}_{2} \mathrm{Cl}$ & 0.1 & $\mathrm{CO}$ \\
\hline & & 235.0269 & & $\mathrm{C}_{11} \mathrm{H}_{8} \mathrm{O}_{2} \mathrm{~N}_{2} \mathrm{Cl}$ & 0.1 & 17 & 224.0110 & $\mathrm{C}_{10} \mathrm{H}_{7} \mathrm{O}_{3} \mathrm{NCl}$ & 0.4 & $\begin{array}{l}\mathrm{HCN} \text {, } \\
\text { addition of } 1 / 2 \\
\mathrm{O}_{2}\end{array}$ \\
\hline & & & & & & & 206.0004 & $\mathrm{C}_{10} \mathrm{H}_{5} \mathrm{O}_{2} \mathrm{NCl}$ & 0.3 & $\begin{array}{l}\mathrm{HCN}, \mathrm{H}_{2} \mathrm{O}, \\
\text { addition of } 1 / 2 \\
\mathrm{O}_{2}\end{array}$ \\
\hline & & & & & & & 196.0160 & $\mathrm{C}_{9} \mathrm{H}_{7} \mathrm{O}_{2} \mathrm{NCl}$ & -0.1 & $\begin{array}{l}\mathrm{HCN}, \mathrm{CO}, \\
\text { addition of } 1 / 2 \\
\mathrm{O}_{2}\end{array}$ \\
\hline & & & & & & & 178.0054 & $\mathrm{C}_{9} \mathrm{H}_{5} \mathrm{ONCl}$ & -0.3 & $\begin{array}{l}\mathrm{HCN} \text {, } \mathrm{CO} \text {, } \\
\mathrm{H}_{2} \mathrm{O} \text {, addition } \\
\text { of } 1 / 2 \mathrm{O}_{2}\end{array}$ \\
\hline & & & 224.0109 & $\mathrm{C}_{10} \mathrm{H}_{7} \mathrm{O}_{3} \mathrm{NCl}$ & -0.2 & 25 & 206.0003 & $\mathrm{C}_{10} \mathrm{H}_{5} \mathrm{O}_{2} \mathrm{NCl}$ & -0.2 & $\mathrm{H}_{2} \mathrm{O}$ \\
\hline & & & & & & & 196.0160 & $\mathrm{C}_{9} \mathrm{H}_{7} \mathrm{O}_{2} \mathrm{NCl}$ & -0.1 & co \\
\hline & & & & & & & 178.0054 & $\mathrm{C}_{9} \mathrm{H}_{5} \mathrm{ONCl}$ & -0.3 & $\mathrm{H}_{2} \mathrm{O}, \mathrm{CO}$ \\
\hline & & & 206.0003 & $\mathrm{C}_{10} \mathrm{H}_{5} \mathrm{O}_{2} \mathrm{NCl}$ & -0.2 & 20 & 224.0110 & $\mathrm{C}_{10} \mathrm{H}_{7} \mathrm{O}_{3} \mathrm{NCl}$ & 0.4 & $\begin{array}{l}\text { addition of } \\
\mathrm{H}_{2} \mathrm{O}\end{array}$ \\
\hline & & & & & & & 196.0160 & $\mathrm{C}_{9} \mathrm{H}_{7} \mathrm{O}_{2} \mathrm{NCl}$ & -0.1 & $\mathrm{H}_{2} \mathrm{O}$ \\
\hline & & & & & & & 178.0053 & $\mathrm{C}_{9} \mathrm{H}_{5} \mathrm{ONCl}$ & -0.5 & $\mathrm{CO}$ \\
\hline & & & & & & & 150.0104 & $\mathrm{C}_{8} \mathrm{H}_{5} \mathrm{NCl}$ & -0.9 & $\operatorname{CO}(2 x)$ \\
\hline \multirow[t]{7}{*}{3} & 224.0110 & & & $\mathrm{C}_{10} \mathrm{H}_{7} \mathrm{O}_{3} \mathrm{NCl}$ & 0.4 & 40 & 206.0004 & $\mathrm{C}_{10} \mathrm{H}_{5} \mathrm{O}_{2} \mathrm{NCl}$ & 0.5 & $\mathrm{H}_{2} \mathrm{O}$ \\
\hline & & & & & & & 196.0160 & $\mathrm{C}_{9} \mathrm{H}_{7} \mathrm{O}_{2} \mathrm{NCl}$ & -0.1 & $\mathrm{co}$ \\
\hline & & & & & & & 178.0054 & $\mathrm{C}_{9} \mathrm{H}_{5} \mathrm{ONCl}$ & -0.3 & $\mathrm{H}_{2} \mathrm{O}, \mathrm{CO}$ \\
\hline & & 206.0004 & & $\mathrm{C}_{10} \mathrm{H}_{5} \mathrm{O}_{2} \mathrm{NCl}$ & 0.3 & 20 & 224.0110 & $\mathrm{C}_{10} \mathrm{H}_{7} \mathrm{O}_{3} \mathrm{NCl}$ & 0.4 & $\begin{array}{l}\text { addition of } \\
\mathrm{H}_{2} \mathrm{O}\end{array}$ \\
\hline & & & & & & & 196.0161 & $\mathrm{C}_{9} \mathrm{H}_{7} \mathrm{O}_{2} \mathrm{NCl}$ & 0.6 & $\mathrm{H}_{2} \mathrm{O}$ \\
\hline & & & & & & & 178.0055 & $\mathrm{C}_{9} \mathrm{H}_{5} \mathrm{ONCl}$ & 0.5 & $\mathrm{CO}$ \\
\hline & & & & & & & 150.0105 & $\mathrm{C}_{8} \mathrm{H}_{5} \mathrm{NCl}$ & -0.1 & $\operatorname{CO}(2 x)$ \\
\hline \multirow[t]{7}{*}{4} & 238.0265 & & & $\mathrm{C}_{11} \mathrm{H}_{9} \mathrm{O}_{3} \mathrm{NCl}$ & -0.1 & 16 & 224.0109 & $\mathrm{C}_{10} \mathrm{H}_{7} \mathrm{O}_{3} \mathrm{NCl}$ & 0.1 & $\mathrm{CH}_{2}$ \\
\hline & & & & & & & 206.0003 & $\mathrm{C}_{10} \mathrm{H}_{5} \mathrm{O}_{2} \mathrm{NCl}$ & 0.0 & $\mathrm{CH}_{2}, \mathrm{H}_{2} \mathrm{O}$ \\
\hline & & & & & & & 196.0160 & $\mathrm{C}_{9} \mathrm{H}_{7} \mathrm{O}_{2} \mathrm{NCl}$ & -0.1 & $\mathrm{CH}_{2}, \mathrm{CO}$ \\
\hline & & & & & & & 178.0053 & $\mathrm{C}_{9} \mathrm{H}_{5} \mathrm{ONCl}$ & -0.6 & $\mathrm{CH}_{2}, \mathrm{CO}, \mathrm{H}_{2} \mathrm{O}$ \\
\hline & & 224.0108 & & $\mathrm{C}_{10} \mathrm{H}_{7} \mathrm{O}_{3} \mathrm{NCl}$ & -0.4 & 40 & 206.0003 & $\mathrm{C}_{10} \mathrm{H}_{5} \mathrm{O}_{2} \mathrm{NCl}$ & -0.2 & $\mathrm{H}_{2} \mathrm{O}$ \\
\hline & & & & & & & 196.0159 & $\mathrm{C}_{9} \mathrm{H}_{7} \mathrm{O}_{2} \mathrm{NCl}$ & -0.5 & $\mathrm{CO}$ \\
\hline & & & & & & & 178.0053 & $\mathrm{C}_{9} \mathrm{H}_{5} \mathrm{ONCl}$ & -0.5 & $\mathrm{H}_{2} \mathrm{O}, \mathrm{CO}$ \\
\hline \multirow[t]{11}{*}{5} & 285.0582 & & & $\mathrm{C}_{12} \mathrm{H}_{6} \mathrm{D}_{4} \mathrm{O}_{4} \mathrm{~N}_{2} \mathrm{Cl}$ & 2.5 & 15 & 265.0350 & $\mathrm{C}_{12} \mathrm{H}_{6} \mathrm{D}_{2} \mathrm{O}_{3} \mathrm{~N}_{2} \mathrm{Cl}$ & & $\mathrm{D}_{2} \mathrm{O}$ \\
\hline & & & & & & & 237.0400 & $\mathrm{C}_{11} \mathrm{H}_{6} \mathrm{D}_{2} \mathrm{O}_{2} \mathrm{~N}_{2} \mathrm{Cl}$ & 2.2 & $\mathrm{D}_{2} \mathrm{O}, \mathrm{CO}$ \\
\hline & & & & & & & 227.0302 & $\mathrm{C}_{10} \mathrm{H}_{4} \mathrm{D}_{3} \mathrm{O}_{3} \mathrm{NCl}$ & 2.0 & $\mathrm{C}_{2} \mathrm{H}_{2} \mathrm{DNO}$ \\
\hline & & & & & & & 225.0174 & $\mathrm{C}_{10} \mathrm{H}_{6} \mathrm{DO}_{3} \mathrm{NCl}$ & 1.1 & $\begin{array}{l}\mathrm{D}_{2} \mathrm{O}, \mathrm{CO}, \\
\mathrm{DCN} \text {, } \\
\text { addition of } 1 / 2 \\
\mathrm{O}_{2}\end{array}$ \\
\hline & & & & & & & 207.0068 & $\mathrm{C}_{10} \mathrm{H}_{4} \mathrm{DO}_{2} \mathrm{NCl}$ & 0.8 & $\begin{array}{l}\mathrm{D}_{2} \mathrm{O}, \mathrm{H}_{2} \mathrm{O}, \\
\mathrm{CO}, \mathrm{DCN}, \\
\text { addition of } 1 / 2 \\
\mathrm{O}_{2}\end{array}$ \\
\hline & & 237.0400 & & $\mathrm{C}_{11} \mathrm{H}_{6} \mathrm{D}_{2} \mathrm{O}_{2} \mathrm{~N}_{2} \mathrm{Cl}$ & 2.2 & 20 & 225.0175 & $\mathrm{C}_{10} \mathrm{H}_{6} \mathrm{DO}_{3} \mathrm{NCl}$ & 1.5 & $\begin{array}{l}\mathrm{DCN} \text {, } \\
\text { addition of } 1 / 2 \\
\mathrm{O}_{2}\end{array}$ \\
\hline & & & & & & & 207.0068 & $\mathrm{C}_{10} \mathrm{H}_{4} \mathrm{DO}_{2} \mathrm{NCl}$ & 0.8 & $\begin{array}{l}\mathrm{DCN}, \mathrm{H}_{2} \mathrm{O} \text {, } \\
\text { addition of } 1 / 2 \\
\mathrm{O}_{2}\end{array}$ \\
\hline & & & 225.0174 & $\mathrm{C}_{10} \mathrm{H}_{6} \mathrm{DO}_{3} \mathrm{NCl}$ & 1.0 & 20 & 207.0067 & $\mathrm{C}_{10} \mathrm{H}_{4} \mathrm{DO}_{2} \mathrm{NCl}$ & 0.7 & $\mathrm{H}_{2} \mathrm{O}$ \\
\hline & & & 207.0068 & $\mathrm{C}_{10} \mathrm{H}_{4} \mathrm{DO}_{2} \mathrm{NCl}$ & 0.8 & 12 & 225.0174 & $\mathrm{C}_{10} \mathrm{H}_{6} \mathrm{DO}_{3} \mathrm{NCl}$ & 1.0 & $\begin{array}{l}\text { addition of } \\
\mathrm{H}_{2} \mathrm{O}\end{array}$ \\
\hline & & & & & & & 179.0118 & $\mathrm{C}_{9} \mathrm{H}_{4} \mathrm{DONCl}$ & 0.4 & $\mathrm{co}$ \\
\hline & & & & & & & 151.0167 & $\mathrm{C}_{8} \mathrm{H}_{4} \mathrm{DNCl}$ & -0.3 & $\mathrm{CO}(2 \mathrm{x})$ \\
\hline
\end{tabular}

$(+18 \mathrm{u}$, Table 1). The source of the added water molecule remained unclear, but the use of deuterium oxide and water ${ }^{18} \mathrm{O}$ as solvents for Compound 2 in
offline-ESI-MS/MS experiments excluded the possibility that it originated from the solvation/ionization process. No shifts due to either ${ }^{18} \mathrm{O}$ - or $\mathrm{D}_{2} \mathrm{O}$-uptake 
Route 1<smiles></smiles>

$m / z 281$

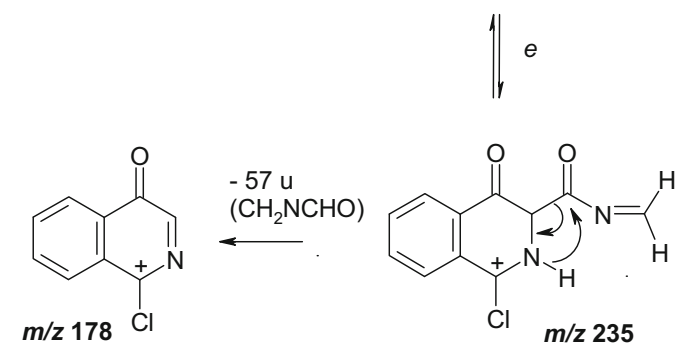<smiles></smiles><smiles>c1ccccc1</smiles><smiles></smiles>
$-18 \mathrm{u} \uparrow+18 \mathrm{u}$ $\left(\mathrm{H}_{2} \mathrm{O}\right) \downarrow\left(\mathrm{H}_{2} \mathrm{O}\right)$<smiles>OC1=c2ccccc2=C(Cl)NN1</smiles><smiles></smiles>

$-28 \mathrm{u}$ (CO)

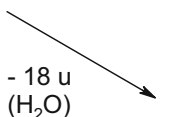<smiles>OC1=[C+]N=C(Cl)c2ccccc21</smiles>

\section{Route 2}

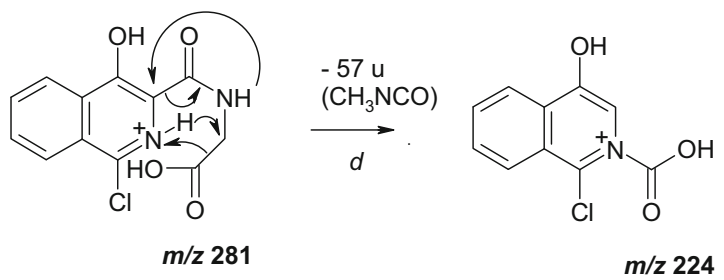

Scheme 2. Proposed dissociation pathway of Compound 2 [(1-chloro-4-hydroxy-isoquinoline-3carbonyl)-amino]-acetic acid.

were observed for the regenerated ion at $\mathrm{m} / \mathrm{z} 224$ (data not shown). The efficiency of restoration was surprisingly high, which allowed to conduct "ping-pong" MS/MS experiments between $m / z 224$ and $m / z$ 206. The product ion at $\mathrm{m} / \mathrm{z} 224$ was dissociated to $\mathrm{m} / \mathrm{z} 206$ at a normalized collision energy of 25 (arbitrary units), and the subsequent isolation and storage of $\mathrm{m} / \mathrm{z} 206$ (normalized collision energy set to 5 arbitrary units) yielded $\mathrm{m} / \mathrm{z} 224$ in high amounts that enabled $\mathrm{MS}^{7}$ experiments going forth and back between the two precursor-/ product ions.

\section{Conclusions}

The mass spectrometric behavior of selected substituted isoquinolines, which possess great potential for clinical utility as prolylhydroxylase inhibitors, was studied, and unusual dissociation pathways were observed using in-time and in-space tandem mass spectrometry. The formation of a particularly favored 3-carboxylic acid structure was suggested based on various MS experiments and analyses of synthetically derived compounds comprising solid-phase structures of assumed gas phase-derived product ions. Detailed mechanistic studies employing for instance density functional theory (DFT) calculation as well as measurements of additional structurally related substances might clarify which factors are essential for the observed phenomena and allow the identification of the major driving force.

\section{Acknowledgments}

The authors acknowledge support of this study from the Manfred Donike Institute for Doping Analysis, Cologne, Germany.

\section{References}

1. Pihlajaniemi, T.; Myllyla, R., Kivirikko, K. I. Prolyl 4-Hydroxylase and Its Role in Collagen Synthesis. J. Hepatol. 1991, 13(Supp 3), S2-S7.

2. Kivirikko, K. I.; Helaakoski, T.; Tasanen, K.; Vuori, K.; Myllyla, R.; Parkkonen, T.; Pihlajaniemi, T. Molecular Biology of Prolyl 4-Hydroxylase. Ann. N.Y. Acad. Sci. 1990, 580, 132-142.

3. Prockop, D. J.; Kivirikko, K. I. Collagens: Molecular Biology, Diseases, and Potentials for Therapy. Annu. Rev. Biochem. 1995, 64, 403-434.

4. Hirsilä, M.; Koivunen, P.; Günzler, V.; Kivirikko, K.; Myllyharju, J. Characterization of the Human Prolyl 4-Hydroxylases that Modify the Hypoxia-Inducible Factor. J. Biol. Chem. 2003, 278, 30772-30780.

5. Epstein, A. C.; Gleadle, J. M.; McNeill, L. A.; Hewitson, K. S.; O'Rourke, J.; Mole, D. R.; Mukherji, M.; Metzen, E.; Wilson, M. I.; Dhanda, A.; Tian, Y. M.; Masson, N.; Hamilton, D. L.; Jaakkola, P.; Barstead, R.; Hodgkin, J.; Maxwell, P. H.; Pugh, C. W.; Schofield, C. J.; Ratcliffe, P. J. C. elegans EGL-9 and Mammalian Homologs Define a Family of Dioxygenases that Regulate HIF by Prolyl hydroxylation. Cell 2001, 107, 43-54.

6. Bruick, R. K.; McKnight, S. L. A Conserved Family of Prolyl-4-Hydroxylases that Modify HIF. Science 2001, 294, 1337-1340.

7. Jaakkola, P.; Mole, D. R.; Tian, Y. M.; Wilson, M. I.; Gielbert, J.; Gaskell, S. J.; Kriegsheim, A.; Hebestreit, H. F.; Mukherji, M.; Schofield, C. J.; Maxwell, P. H.; Pugh, C. W.; Ratcliffe, P. J. Targeting of HIF- $\alpha$ to the von Hippel-Lindau ubiquitilation complex by O2-regulated prolyl hydroxylation. Science 2001, 292, 468-472.

8. Ivan, M.; Kondo, K.; Yang, H.; Kim, W.; Valiando, J.; Ohh, M.; Salic, A.; Asara, J. M.; Lane, W. S.; Kaelin, W. G., Jr. HIF $\alpha$ Targeted for VHLMediated Destruction by Proline Hydroxylation: Implications for O2 Sensing. Science 2001, 292, 464-468.

9. Yu, F.; White, S. B.; Zhao, Q.; Lee, F. S. HIF-1 $\alpha$ Binding to VHL is Regulated by Stimulus-Sensitive Proline Hydroxylation. Proc. Natl. Acad. Sci. U.S.A. 2001, 98, 9630-9635.

10. Safran, M.; Kaelin, W. G., Jr. HIF Hydroxylation and the Mammalian Oxygen-Sensing Pathway. J. Clin. Invest. 2003, 111, 779-783.

11. Metzen, E.; Ratcliffe, P. HIF Hydroxylation and Cellular Oxygen Sensing. Biol. Chem. 2004, 385, 223-230. 
12. Bruick, R. Oxygen Sensing in the Hypoxic Response Pathway: Regulation of the Hypoxia-Inducible Transcription Factor. Genes Dev. 2003, 17, 2614-2623.

13. Warnecke, C.; Griethe, W.; Weidemann, A.; Jurgensen, J.; Willam, C.; Bachmann, S.; Ivashchenko, Y.; Wagner, I.; Frei, U.; Wiesener, M. Eckardt, K. Activation of the Hypoxia-Inducible Factor Pathway and Stimulation of Angiogenesis by Application of Prolyl Hydroxylase Inhibitors. FASEB J. 2003, 17, 1186-1188.

14. Bruick, R. K.; McKnight, S. L. Building Better Vasculature. Genes Dev. 2001, 15, 2497-2502.

15. Jelkmann, W. Molecular Biology of Erythropoietin. Intern. Med. 2004, 43, 649-659.

16. Ratcliffe, P. From Erythropoietin to Oxygen: Hypoxia-Inducible Factor Hydroxylases and the Hypoxia Signal Pathway. Blood Purif. 2002, 20, $445-450$.

17. del Peso, L.; Castellanos, M.; Temes, E.; Martin-Puig, S.; Cuevas, Y.; Olmos, G.; Landazuri, M. The von Hippel Lindau/Hypoxia-Inducible Factor (HIF) Pathway Regulates the Transcription of the HIF-Proline Hydroxylase Genes in Response to Low Oxygen. J. Biol. Chem. 2003, 278, 48690-48695.

18. Nietfeld, J.; de Jong, L.; Kemp, A.The Influence of 2-Oxoglutarate on the Activity of Prolyl 4-Hydroxylase. Biochim. Biophys. Acta. 1982, 704, 321-325.

19. Mole, D.; Schlemminger, I.; McNeill, L.; Hewitson, K.; Pugh, C.; Ratcliffe, P.; Schofield, C. 2-Oxoglutarate Analogue Inhibitors of HIF Prolyl Hydroxylase. Bioorg. Med. Chem. Lett. 2003, 13, 2677-2680.

20. Cunliffe, C.; Franklin, T. Inhibition of Prolyl 4-Hydroxylase by $\mathrm{Hy}-$ droxyanthraquinones. Biochem. J. 1986, 239, 311-315.

21. Dowell, R.; Hadley, E. Novel Inhibitors of Prolyl 4-Hydroxylase. J. Med. Chem. 1992, 35, 800-804.

22. Wang, J.; Buss, J.; Chen, G.; Ponka, P.; Pantopoulos, K. The Prolyl 4-Hydroxylase Inhibitor Ethyl-3,4-Dihydroxybenzoate Generates Effective Iron Deficiency in Cultured Cells. FEBS Lett. 2002, 529, 309-312.

23. Warshakoon, N. C.; Wu, S.; Boyer, A.; Kawamoto, R.; Sheville, J.; Renock, S.; Xu, K.; Pokross, M.; Zhou, S.; Winter, C.; Walter, R.; Mekel, M.; Evdokimov, A. G. Structure-Based Design, Synthesis, and SAR
Evaluation of a New Series of 8-Hydroxyquinolines as HIF-1 $\alpha$ Prolyl Hydroxylase Inhibitors. Bioorg. Med. Chem. Lett. 2006, 16, 5517-5522.

24. Warshakoon, N. C.; Wu, S.; Boyer, A.; Kawamoto, R.; Renock, S.; Xu, K. Pokross, M.; Evdokimov, A. G.; Zhou, S.; Winter, C.; Walter, R.; Mekel, M. Design and Synthesis of a Series of Novel Pyrazolopyridines as HIF-1 $\alpha$ Prolyl Hydroxylase Inhibitors. Bioorg. Med. Chem. Lett. 2006, 16, 5687-5690.

25. Tucker, H.; Thomas, D. Novel Inhibitors of Prolyl 4-Hydroxylase. 2. 5-Amide Substituted pyridine-2-carboxylic acids. J. Med. Chem. 1992, 35, $804-807$.

26. Hales, N.; Beattie, J. Novel Inhibitors of Prolyl 4-Hydroxylase. 5. The Intriguing Structure-Activity Relationships Seen with 2,2'-Bipyridine and Its 5,5'-Dicarboxylic Acid Derivatives. J. Med. Chem. 1993, 36 3853-3858.

27. Cunliffe, C.; Franklin, T.; Hales, N.; Hill, G. Novel Inhibitors of Prolyl 4-Hydroxylase. 3. Inhibition by the Substrate Analogue N-Oxaloglycine and Its Derivatives. J. Med. Chem. 1992, 35, 2652-2658.

28. Baader, E.; Tschank, G.; Baringhaus, K.; Burghard, H.; Gunzler, V. Inhibition of Prolyl 4-Hydroxylase by Oxalyl Amino Acid Derivatives in Vitro, in Isolated Microsomes and in Embryonic Chicken Tissues. Biochem. J. 1994, 300, 525-530.

29. Fibrogen Inc. Development Pipeline. 2007, http://www.fibrogen.com/ pipeline/chart/anemia.html\#mid (accessed 09-20-2007).

30. Wang, Q.; Gou, G.; Guenzler, V.; Neff, T.; Klaus, S.; Turtle, E.; Molineaux, C.; Yeowell, D., Lin, A. Stimulation of Erythropoiesis and Treatment of Anemia in Rodents by Oral Administration of FG-2216, a Nove HIF-Prolyl Hydroxylase Inhibitor. J. Am. Soc. Nephrol. 2004, 15, 773A.

31. Hsieh, M. M.; Linde, N. S.; Wynter, A.; Metzger, M.; Wong, C.; Langsetmo, I.; Lin, A.; Smith, R.; Rodgers, G. P.; Donahue, R. E.; Klaus, S. J.; Tisdale, J. F. HIF Prolyl Hydroxylase Inhibition Results in Endogenous Erythropoietin Induction, Erythrocytosis, and Modest Fetal Hemoglobin Expression in Rhesus Macaques. Blood 2007, 110, 2140-2147.

32. Suzuki, M.; Nunami, K.; Matsumoto, K.; Yoneda, N.; Miyoshi, M. A Facile Synthesis of 1-Oxo-1,2-Dihydroxyisoquinoline-3-Carboxylate and 2-Pyridone-6-Carboxylate Derivatives. Synthesis 1978, 461-462.

33. Fibrogen. EP 1538160 A1, European Patent Office: 2005. 